\title{
青藏高原植被生态系统垂直分布变化的情景模拟
}

\author{
范泽孟 $1,2,3$, * \\ 1 中国科学院地理科学与资源研究所,资源与环境信息系统国家重点实验室, 北京 100101 \\ 2 中国科学院大学资源与环境学院, 北京 100049 \\ 3 江苏省地理信息资源开发与利用协同创新中心，南京 210023
}

摘要: 如何模拟和揭示青藏高原植被生态系统垂直分布在全球气候变化驱动下的时空变化情景, 对定量解析青藏高原陆地生态 系统对气候变化响应效应具有重要意义。该论文基于 Holdridge life zone(HLZ) 模型,结合数字高程模型(DEM) 数据,改变模型 输人参数模式,发展了改进型 HLZ 生态系统模型。结合 1981-2010(T0) 时段的气候观测数据和 IPCC CMIP5 RCP2.6、RCP4.5、 RCP8.5 三种情景 2011-2040(T1)、2041-2070(T2)、2071-2100(T3)三个时段气候情景数据,实现了青藏高原植被生态系统 垂直分布的时空变化情景模拟。引人生态系统平均中心时空偏移趋势模型和生态多样性指数模型, 定量揭示了青藏高原植被 生态系统在不同垂直带上的时空变化情景。结果显示: 青藏高原共有 16 种植被生态系统类型; 冰雪/冰原、高山潮湿苔原和亚 高山湿润森林为青藏高原主要的植被生态系统类型, 其面积之和占到了青藏高原总面积的 $56.26 \%$; 高山干苔原、亚高山潮湿森 林、山地灌丛、山地湿润森林和荒漠等对气候变化的敏感性总体上高于其它类型; 在 T0-T3 期间, 青藏高原的高山湿润苔原、高 山干苔原、荒漠呈持续减少趋势, 平均每 10 年将分别减少 $1.96 \times 10^{4} \mathrm{~km}^{2} 、 0.15 \times 10^{4} \mathrm{~km}^{2}$ 和 $1.58 \times 10^{4} \mathrm{~km}^{2}$; 亚高山潮湿森林、山地湿 润森林和山地灌丛呈持续增加趋势, 平均每 10 年将分别增加 $3.42 \times 10^{4} \mathrm{~km}^{2} 、 2.98 \times 10^{4} \mathrm{~km}^{2}$ 和 $1.19 \times 10^{4} \mathrm{~km}^{2} ; \mathrm{RCP} 8.5$ 情景下青藏高 原的植被生态系统平均中心的偏移幅度最大, RCP4.5 情景下的偏移幅度次之, 而 RCP2.6 情景下的偏移幅度最小。另外, 在三 种气候变化情景驱动下, 青藏高原植被生态系统的生态多样性呈减少趋势。总之, 未来不同情景的气候变化将直接影响青藏高 原植被生态系统的时空分布格局及其生态多样性,气候变化强度越高, 影响就越大,而且气候变化对青藏高原植被生态系统的 影响呈现出从低海拔到高海拔递增的影响效应。

关键词: 植被生态系统; 垂直分布; 时空变化; 情景模拟; 青藏高原

\section{Scenario simulation of vertical distribution changes of vegetation ecosystem in the Qinghai-Tibet Plateau}

\author{
FAN Zemeng ${ }^{1,2,3, *}$ \\ 1 State Key Laboratory of Resources and Environmental Information System, Institute of Geographic Sciences and Natural Resources Research, Chinese Academy \\ of Sciences, Beijing 100101, China \\ 2 College of Resources and Environment, University of Chinese Academy of Sciences, Beijing 100049, China \\ 3 Jiangsu Center for Collaborative Innovation in Geographical Information Resource Development and Application, Nanjing 210023, China
}

\begin{abstract}
How to simulate and reveal the spatiotemporal change scenarios of vertical distribution of vegetation ecosystem in Qinghai-Tibet Plateau under the future global climate change is very beneficial for quantitatively explicating the response of terrestrial ecosystem to climate change. In this study, the improved Holdridge Life Zone (iHLZ) ecosystem model was developed by combing the HLZ model and Digital Elevation Model (DEM) data. Based on the climate observation data in
\end{abstract}

基金项目: 国家重点研发计划项目 (2018YFC0507202,2017YFA0603702); 国家自然科学基金项目 (41971358,41930647)

收稿日期:2020-11-11; 采用日期:2021-06-28

* 通讯作者 Corresponding author.E-mail: fanzm@ lreis.ac.cn 
the T0 (1981-2010) period, and the Intergovernmental Panel on Climate Change Coupled Model Intercomparison Project ( IPCC CMIP5) RCP2.6, RCP4.5, and RCP8.5 climate scenario data in the T1 (2011-2040), T2 (2041-2070), and T3 ( 2071-2100) periods, the vertical scenarios of vegetation ecosystem distributed in Qinghai-Tibet Plateau were simulated. The spatiotemporal shifting model of ecosystem mean center and ecological diversity index were introduced to explicitly analyze the change of vegetation ecosystem in different vertical zones of Qinghai-Tibet Plateau. The results show that there are 16 mountain vegetation ecosystem types in Qinghai-Tibet Plateau. The ice snow/ice, alpine moist tundra, and subalpine moist forest are the major vegetation ecosystem types and covers 56.26\% of the total area of Qinghai-Tibet Plateau. -The sensitivity of alpine dry tundra, subalpine moist forest, mountain shrub, and desert to the climate change would be generally more than other types in Qinghai-Tibet Plateau under the three scenarios of RCP2.6, RCP4.5, and RCP8.5. The areas of alpine moist tundra, alpine dry tundra and desert show a decreasing trend, which will be decreased by $1.96 \times 10^{4}$ $\mathrm{km}^{2}, 0.15 \times 10^{4} \mathrm{~km}^{2}$ and $1.58 \times 10^{4} \mathrm{~km}^{2}$ per decade between T0 and T3, respectively. The areas of subalpine moist forest, mountain moist forest and mountain shrub show an increasing trend, which will be increased by $3.42 \times 10^{4} \mathrm{~km}^{2}, 2.98 \times 10^{4}$ $\mathrm{km}^{2}$ and $1.19 \times 10^{4} \mathrm{~km}^{2}$ per decade between T0 and T3, respectively. The mean center in the vegetation ecosystem has the largest shift distance under the scenario RCP8.5, followed by the scenario RCP4.5, and that has the least shift distance under the scenario RCP8.5. The ecological diversity of vegetation ecosystem will be reduced generally in Qinghai-Tibet Plateau in the future. In general, the greater climate change will lead to the larger impacts of climate change on ecosystem diversity, which shows an increasing trend from low altitude to high altitude in the Qinghai-Tibet Plateau.

Key Words: vegetation ecosystem; vertical distribution; spatiotemporal change; scenario simulation; Qinghai-Tibet plateau

植被生态系统是陆地生态系统的重要组成部分,其时空分布格局的演替和变化对全球变化有响应和反馈 作用 ${ }^{[-3]}$ 。气温和降水等关键气候因子的时空变化,通过影响对植物的生理生长和土壤湿度等生境条件 ${ }^{[4-6]}$, 进而导致植被生态系统类型、结构及空间格局的演替变化 ${ }^{[7-11]}$ 。定量模拟和解析植被生态系统对全球变化的 响应、适应及其反馈机制已成为全球变化及生态学研究领域的热点和前沿问题 ${ }^{[12-15]}$ 。因此,如何利用气候观 测数据并结合根据不同全球气候情景模式数据, 模拟预测全球变化影响下的植被生态系统长期演化趋势, 是 深人揭示和厘清究生态系统结构、功能及其关键过程对人类活动影响和全球变化的响应与适应机制亟需研究 的焦点问题之一 ${ }^{[12,16]}$ 。另外, 植被生态系统模型的长足发展, 使在不同尺度上实现植被生态系统结构及其分 布的时空模拟逐渐精细和深人 ${ }^{[16-17]}$ 。目前关于气候与植被生态系统相互作用的主流模型包括 HLZ 生态系统 模型 ${ }^{[18]} 、$ BOX 模型 ${ }^{[19]} 、$ DOLY 模型 ${ }^{[20]}$ 、MAPSS 模型 ${ }^{[21]}$ 、IBIS 模型 ${ }^{[22]}$ 和 LPJ-DGVM 模型 ${ }^{[23]}$ 等。其中, HLZ 生 态系统模型可以依据年平均生物温度、年降水量和潜在蒸散比率 3 个关键的生物气候要素, 实现对不同植被 生态系统类型的定量判别和时空模拟 ${ }^{[24-26]}$ 。由于其模型参数相对于其它模型更为简单, 基础数据容易获取, 被国内外学者广泛应用 ${ }^{[27-30]}$ 。

青藏高原被称之为“世界屋脊”和“地球第三极”, 是亚洲乃至北半球气候变化的“感应器”和“敏感

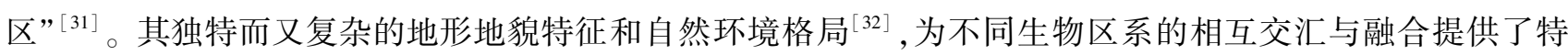
定的空间,使青藏高原成为全球生物多样性保护的 25 个热点地区之一 ${ }^{[31,33-34]}$ 。自 20 世纪以来, 国内外学者 对青藏高原的地表过程开展了大量的持续性研究,且在高原气候变化、冰川冻土变化、生态系统碳过程、土地 覆被变化、生态退化区防治等方面取得了系列研究进展 ${ }^{[35-37]}$ 。在青藏高原植被生态系统方面, 现有研究主要 集中于气候植被模型的研究进展 ${ }^{[38]}$, 青藏高原局部区域的遥感植被参数提取分析 ${ }^{[39]}$ 、植被覆盖度的定量估 算 ${ }^{[40]}$ 定量估算、以及年际植被变化规律 ${ }^{[41]}$ 等方面。

以上研究主要是对过去趋势以及青藏高原的局部区域的模拟分析, 缺乏对整个区域内的植被生态系统在 气候变化驱动下的未来时空分布变化特征模拟的相关研究, 尤其很少从垂直分布的角度对整个青藏高原植被 生态系统垂直分布的定量解析和模拟预测。因此,该论文旨在基于 Holdridge life zone( HLZ) 模型, 结合数字 
高程模型 (DEM) 数据, 改变模型输人参数模式, 发展能够从垂直分布角度定量刻画和模拟青藏高原植被生态 系统垂直分布变化的改进型 HLZ 生态系统模型, 进而结合 1981-2010 (T0) 时段的气候观测数据, 对青藏高 原植被生态系统的空间分布格局进行模拟, 在采用 CMIP5 RCP2.6、RCP4.5 和 RCP8.5 三种情景数据, 从植被 分布垂直地带性的角度, 对青藏高原 2011-2040（T1）、2041-2070（T2）和 2071-2100（T3）三个未来时段 的植被生态系统垂直分布的时空变化情景进行模拟。另外,引人生态系统时空分析模型 ${ }^{[25]}$ 和生态多样性指 数模型 ${ }^{[18]}$, 定量求算青藏高原植被生态系统平均中心在未来不同气候情景下的时空演替趋势, 及其生态多样 性变化的未来情景。

\section{1 数据与方法}

\section{1 基础数据收集与处理}

气候数据包括观测数据和模式模拟情景数据。气候观测数据来源于 1981-2010 年位于青藏高原及周边 区域的气象台站。气候情景数据采用 IPCC CMIP5 发布的能代表未来温室气体排放的高中低三种情景 ${ }^{[42]}$, 即: RCP2.6(低排放情景)、RCP4.5(中间排放情景)、RCP8.5 (高排放情景) ( http://www.ipcc-data.org)。青 藏高原的 DEM 数据采用 SRTM 数据, 数据来源于 http://srtm.csi.cgiar.org, 空间分辨率为 $1 \mathrm{~km} \times 1 \mathrm{~km}$ 。

如何对气象站点的观测数据进行空间插值, 以及对气候情景数据进行空间降尺度, 进而获取高质量的气 候要素空间数据, 对于植被生态系统分布特征模拟结果可靠性具有直接影响 ${ }^{[18,43]}$ 。鉴于高精度曲面建模 $(\mathrm{HASM})$ 方法 ${ }^{[44]}$, 能够克服反距离加权模型 (IDW)、三角网模型 ( TIN)、克里金模型 (Kriging)、样条插值模型 (Spline) 等常用方法的理论缺陷并提升模型的模拟精度 ${ }^{[44-45]}$ 。因此, 在进行气候观测数据空间插值和未来气 候情景数据空间降尺度的过程中, 采用 HASM 方法, 并结合经纬度及高程数据, 实现气候观测数据的空间插 值和未来气候情景数据的空间降尺度 ${ }^{[45-46]}$, 分别获得青藏高原 $1 \mathrm{~km} \times 1 \mathrm{~km}$ 空间分辨率的 T0、T1、T2 和 T3 四个 时段的年平均生物温度、年降水量和潜在蒸散比率数据。

\section{2 植被生态系统垂直分布空间模拟模型}

针对青藏高原的地形特征和植被分布的海拔垂直差异, 在对 HLZ (Holdridge life zone) 生态系统模 型 ${ }^{[26-28,47]}$ 进行修正和拓展的基础上, 根据青藏高原的年平均生物温度、年降水量和潜在蒸散比率三个主要的 生物气候要素的高精度空间模拟数据, 建立了青藏高原植被生态系统垂直分布的空间模拟模型, 其理论计算 公式可表征为:

$$
\begin{aligned}
\operatorname{MAB}_{\text {Tibet }}(x, y, t) & =\frac{1}{365} \sum_{j=1}^{365} \operatorname{TEM}_{\text {Tibet }}(j, x, y, t) \\
\operatorname{TAP}_{\text {Tibet }}(x, y, t) & =\sum_{j=1}^{365} P_{\text {Tibet }}(j, x, y, t) \\
\operatorname{PER}_{\text {Tibet }}(x, y, t) & =\frac{58.93 \operatorname{MAB}_{\text {Tibet }}(x, y, t)}{\operatorname{TAP}_{\text {Tibet }}(x, y, t)} \\
\operatorname{HLZ}_{\text {Tibet }, i}(x, y, t) & =\sqrt{\left(M(j, x, y, t)-M_{i 0}\right)^{2}+\left(T(j, x, y, t)-T_{i 0}\right)^{2}+\left(P(j, x, y, t)-P_{i 0}\right)^{2}}
\end{aligned}
$$

式中, $\mathrm{MAB}_{\text {Tibet }}(x, y, t) 、 \mathrm{TAP}_{\text {Tibet }}(x, y, t)$ 和 $\mathrm{PER}_{\text {Tibet }}(x, y, t)$ 分别为青藏高原 $t$ 时刻位置 $(x, y)$ 处的平均生物温度 $\left({ }^{\circ} \mathrm{C}\right)$ 、年降水量 $(\mathrm{mm})$ 和潜在蒸散比率; $\operatorname{TEM}_{\text {Tibet }}(j, x, y, t)$ 和 $P_{\text {Tibet }}(j, x, y, t)$ 分别为青藏高原第 $j$ 天的积温和降 水量; $M(j, x, y, t)=\log _{2} \mathrm{MAB}_{\text {Tibet }}(x, y, t), T(j, x, y, t)=\log _{2} \mathrm{MAB}_{\text {Tibet }}(x, y, t), P(j, x, y, t)=\log _{2} \mathrm{MAB}_{\text {Tibet }}(x, y, t)$; $M_{i 0} 、 T_{i 0}$ 和 $P_{i 0}$ 分别是青藏高原第 $i$ 种植被生态系统类型中心点的 MAB、TAP 和 PER 的判别标准值; HLZ $Z_{\text {Tibet }, i}$ $(x, y, t)$ 为 $t$ 时刻位置 $(x, y)$ 处青藏高原第 $i$ 种植被生态系统类型。

1.3 植被生态系统的斑块连通性和生态多样性指数

斑块连通性是一个可有效计算某一生态系统类型中的动植物扩散传播的平均效率的生态景观指数 ${ }^{[48]}$ 。 因此,引人斑块连通性指数模型对青藏高原植被生态系统景观单元的斑块连通性变化进行定量求算, 可以有 
效揭示在景观层次上青藏高原植被生态系统垂直分布对气候变化的响应情况,理论公式可表达如下:

$$
\begin{aligned}
S_{i, j}(t) & =\frac{8 \sqrt{3} A_{i, j}(t)}{\left(\operatorname{Pr}_{i, j}(t)\right)^{2}} \\
C o(t) & =\sum_{i=1}^{m(t)} \sum_{j=1}^{n_{i}(t)} P_{i, j}(t) \cdot S_{i, j}(t)
\end{aligned}
$$

式中, $t$ 为时间变量; $S_{i, j}(t)$, 为物种在斑块 $(i, j)$ 内的迁移效率指数, $A_{i, j}(t)$ 和 $P r_{i, j}(t)$, 分别为第 $i$ 种植被生 态系统类型第 $j$ 个斑块的面积和周长, $8 \sqrt{3}$ 为正六边形周长的平方与面积的比率; $P_{i, j}(t)$ 为第 $i$ 种植被生态 系统类型第 $j$ 个斑块面积占整个研究区域的面积比率; $C o(t)$ 为 $t$ 时段该生态类型的斑块连通性,且 $0 \leqslant$ $C o(t) \leqslant 1.1$, 当所有斑块均为正六边形时, $C o(t)=1.0$ 。

在求解青藏高原植被生态系统斑块连通性指数的基础上,引人度生态多样性指数模型 ${ }^{[26,48]}$, 并对模型输 人参数对象进行拓展, 即以青藏高原植被生态系统垂直分布的空间分布作为研究对象, 实现青藏高原植被生 态系统多样性的定量计算,进而揭示青藏高原植被生态系统类型丰富度对气候变化的响应机理。模型的理论 公式可表达为

$$
\operatorname{Div}(t)=-\frac{\ln \left(\sum_{i=1}^{m(\varepsilon)}\left(p_{i}(t)\right)^{\frac{1}{2}}\right)^{2}}{\ln (\varepsilon)}
$$

式中, $t$ 为时间变量; $p_{i}(t)$ 为第 $i$ 种植被生态系统类型的概率; $m(\varepsilon)$ 为青藏高原植被生态系统类型的数量; $\varepsilon=\frac{1}{\mathrm{e}+\mathrm{a}}, a$ 研究区总面积, $e$ 取常数值 $2.71828 ; D \operatorname{iv}(t)$ 即为 $t$ 时段青藏高原植被生态系统的生态多样性。

1.4 植被生态系统平均中心偏移的时空分析模型

植被生态系统平均中心时空偏移分析模型, 是一个在求算植被生态系统平均中心分布的基础上,根据其 平均中心的时空偏移距离和方向, 对植被生态系统时空分布格局变化进行定量阐述的空间分析模型 ${ }^{[49]}$ 。通 过植被生态系统平均中心偏移距离的大小可以有效揭示其对气候变化响应的强度,而偏移方向的变化则可以 反映其对气候变化影响的变化频次 ${ }^{[26]}$,理论公式可表达为:

$$
\begin{aligned}
& x_{i}(t)=\sum_{i=1}^{I_{j}(t)} \frac{S_{i j}(t) \cdot X_{i j}(t)}{S_{j}(t)} \\
& y_{i}(t)=\sum_{i=1}^{I_{j}(t)} \frac{S_{i j}(t) \cdot Y_{i j}(t)}{S_{j}(t)}
\end{aligned}
$$

式中, $t$ 为时间变量; $I_{j}(t)$ 第 $j$ 种植被生态系统的斑块数; $S_{i j}(t)$ 为第 $j$ 种植被生态系统第 $i$ 个斑块的面积; $S_{j}(t)$ 为第 $j$ 种植被生态系统的总面积; $X_{i j}(t), Y_{i j}(t)$ 分别为第 $j$ 种植被生态系统第 $i$ 个玟块几何中心的经度和 纬度的坐标值; $x_{j}(t), y_{j}(t)$ 分别为第 $j$ 种植被生态系统的平均中心经度和纬度的坐标值。第 $j$ 种植被生态系 统平均中心的偏移距离和方向可分别为:

$$
\begin{gathered}
d_{j}=\sqrt{\left(x_{j}(t+1)-x_{j}(t)\right)^{2}+\left(y_{j}(t+1)-y_{j}(t)\right)^{2}} \\
\theta_{j}=\operatorname{arctg}\left(\frac{y_{j}(t+1)-y_{j}(t)}{x_{j}(t+1)-x_{j}(t)}\right)
\end{gathered}
$$

式中, $d_{j}$ 为第 $j$ 种植被生态系统平均中心从 $t$ 到 $t+1$ 时段的偏移距离; $\theta_{j}$ 为第 $j$ 种植被生态系统平均中心从 $t$ 到 $t+1$ 时段的偏移角度, $\left(x_{j}(t), y_{j}(t)\right)$ 和 $\left(x_{j}(t+1), y_{j}(t+1)\right)$ 分别代表第 $j$ 种植被生态系统 $t$ 时段和 $t+1$ 时段的平均中心坐标; 当 $345^{\circ}<\theta_{j} \leqslant 15^{\circ}$ 时, 近似认为第 $j$ 种植被生态系统的平均中心从 $t$ 时段到 $t+1$ 时段 向东偏移; 当 $15^{\circ}<\theta_{j} \leqslant 75^{\circ}$ 时, 近似认为第 $j$ 种植被生态系统的平均中心从 $t$ 时段到 $t+1$ 时段向东北方向偏 移; 当 $75^{\circ}<\theta_{j} \leqslant 105^{\circ}$ 时, 近似认为第 $j$ 种植被生态系统的平均中心从 $t$ 时段到 $t+1$ 时段向北偏移; 当 $105^{\circ}<$ $\theta_{j} \leqslant 165^{\circ}$ 时, 近似认为第 $j$ 种植被生态系统的平均中心从 $t$ 时段到 $t+1$ 时段向西北方向偏移; 当 $165^{\circ}<\theta_{j} \leqslant$ $195^{\circ}$ 时, 近似认为第 $j$ 种植被生态系统的平均中心从 $t$ 时段到 $t+1$ 时段向西偏移; 当 $195^{\circ}<\theta_{j} \leqslant 255^{\circ}$ 时, 近似 
认为第 $j$ 种植被生态系统的平均中心从 $t$ 时段到 $t+1$ 时段向西南方向偏移; 当 $255^{\circ}<\theta_{j} \leqslant 285^{\circ}$ 时, 近似认为 第 $j$ 种植被生态系统的平均中心从 $t$ 时段到 $t+1$ 时段向南偏移; 当 $285^{\circ}<\theta_{j} \leqslant 345^{\circ}$ 时, 近似认为第 $j$ 种植被 生态系统的平均中心从 $t$ 时段到 $t+1$ 时段向东南方向偏移。

\section{2 模拟结果}

2.1 青藏高原植被生态系统的空间分布格局

运用 1981-2010(T0) 时段的气候观测数据对青藏 高原植被生态系统垂直分布格局的模拟结果表明 (图 1), 青藏高原共有 17 种植被生态系统类型, 其中, 低山有刺草原在 RCP2.6 和 RCP4.5 情景中均未出现, 仅在 RCP8.5 情景的 T3 时段出现, 其于 16 种植被生态 系统类型垂直分布的总体格局为: 荒漠生态系统类型主 要分布在塔里木盆地的塔克拉玛干沙漠地带及其周围 地区。从青藏高原的山前地带到高海拔地区依次为山 前湿润森林、低山湿润森林、低山干旱生森林、低山荒漠 灌丛、山地湿润森林、山地灌丛、山地草原、亚高山潮湿 森林、亚高山湿润森林、亚高山干旱灌丛、高山雨苔原、 高山潮湿苔原、高山湿润苔原、高山干苔原和冰雪/冰原 等 14 种植被生态系统类型。其中,高山潮湿苔原、亚高 山湿润森林和冰雪/冰原是青藏高原主要的植被生态系 统类型,分别占总面积的 $23.69 \% 、 17.79 \%$ 和 $14.78 \%$ 。 高山潮湿苔原主要分布在青藏高原的中部、西南部和东

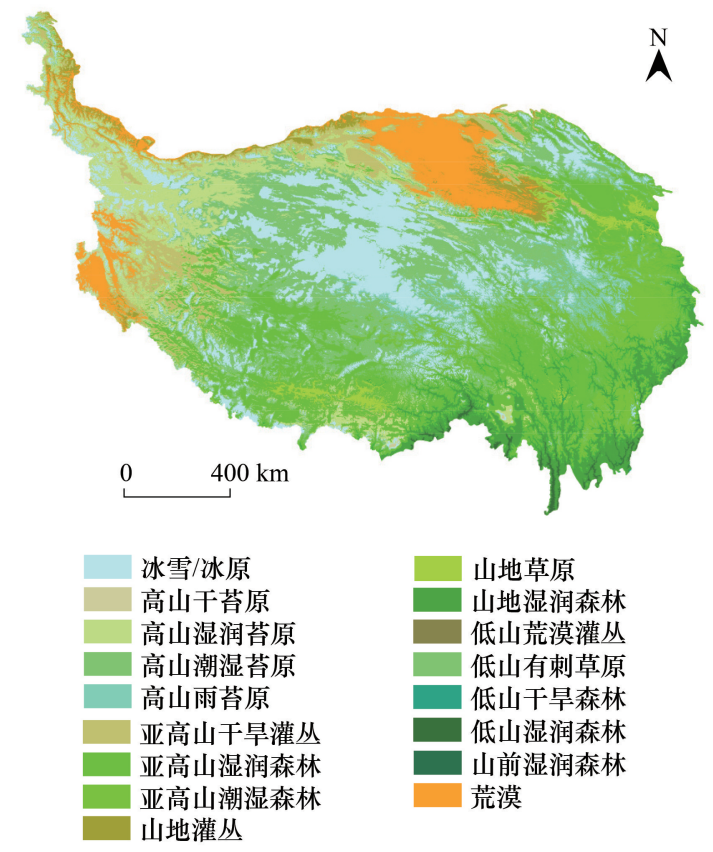

图 1 青藏高原植被生态系统垂直分布的空间格局

Fig. 1 Spatial pattern of vertical distribution of vegetation ecosystem in Qinghai-Tibet Plateau 北部区域,亚高山湿润森林主要分布在青藏高原的南部 和东北部区域,而冰雪/冰原则主要分布在青藏高原的中部、西北、西南和东北部的高海拔区域。

2.2 青藏高原植被生态系统面积的变化情景

对 RCP2.6、RCP4.5 和 RCP8.5 三种情景下的青藏高原植被生态系统模拟结果(图 2-4)进行统计分析表 明,在三种不同强度的气候变化情景下,青藏高原植被生态系统类型的面积在 2010-2100 年间将呈现出不同 的变化趋势和空间差异。

在 RCP2.6 情景下, 高山湿润苔原、荒漠和高山干苔原的面积在 T0-T3 将呈持续减少趋势, 平均每 10 年 分别减少 $1.451 \times 10^{4} \mathrm{~km}^{2} 、 1.343 \times 10^{4} \mathrm{~km}^{2}$ 和 $0.151 \times 10^{4} \mathrm{~km}^{2}$, 其中高山干苔原和荒漠的面积的缩减幅度将分别高 达 $92 \%$ 和 69\%。亚高山潮湿森林、山地湿润森林和山地灌丛的面积将呈持续增加趋势, 平均每 10 年分别增 加 $1.831 \times 10^{4} \mathrm{~km}^{2} 、 1.286 \times 10^{4} \mathrm{~km}^{2}$ 和 $0.903 \times 10^{4} \mathrm{~km}^{2}$, 其中山地灌丛和亚高山潮湿森林面积增加的幅度将分别接 近 170\%和 $105 \%$ 。此结果表明, 高山干苔原、荒漠、山地灌丛、亚高山潮湿森林等植被生态系统类型对气候变 化的敏感性高于其它的植被生态系统类型。

在 RCP4.5 情景下, 冰雪/冰原、高山湿润苔原和荒漠三种植被生态系统类型面积在 T0-T3 时段将呈持 续减少趋势, 平均每 10 年分别减少 $3.445 \times 10^{4} \mathrm{~km}^{2} 、 1.920 \times 10^{4} \mathrm{~km}^{2}$ 和 $1.541 \times 10^{4} \mathrm{~km}^{2}$ 。亚高山潮湿森林、山地湿 润森林和山地灌丛三种植被生态系统类型的面积增加最多,在 T0-T3 时段平均每 10 年将分别增加 $3.266 \times$ $10^{4} \mathrm{~km}^{2} 、 2.485 \times 10^{4} \mathrm{~km}^{2}$ 和 $1.240 \times 10^{4} \mathrm{~km}^{2}$ 。从 $\mathrm{T} 0$ 到 $\mathrm{T} 3$ 时段, 高山干苔原和荒漠的面积减少幅度分别为 $95 \%$ 和 $79 \%$, 而亚高山潮湿森林、山地灌丛、山地湿润森林和低山湿润森林面积的增加幅度将超过 $130 \%$ 。此结果表 明, 在 RCP4.5 情景驱动下的高山干苔原、荒漠、山地灌丛、亚高山潮湿森林、低山湿润森林、山地湿润森林等 植被生态系统类型对气候变化的敏感性高于其它的植被生态系统类型。 

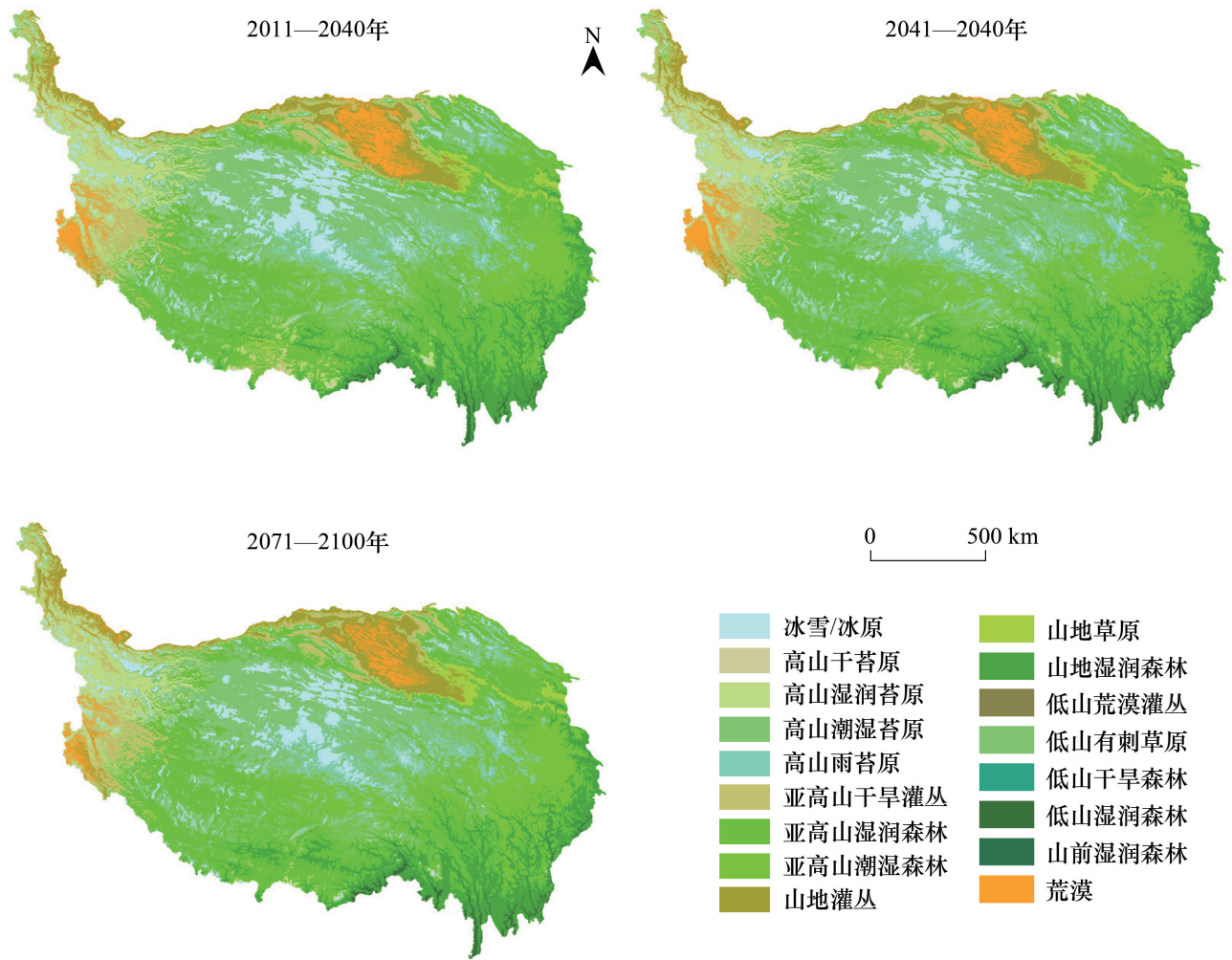

图 2 基于 RCP2.6 情景的青藏高原植被生态系统在 T1 (2011-2040)、T2 (2041-2040) 和 T3 (2071-2100) 三个时段的时空分布 Fig.2 Spatiotemporal distribution of vegetation ecosystem in Qinghai-Tibet Plateau under scenario RCP2.6 during the three periods of T1 (2011-2040), T2 (2041-2070) and T3 (2071-2100)
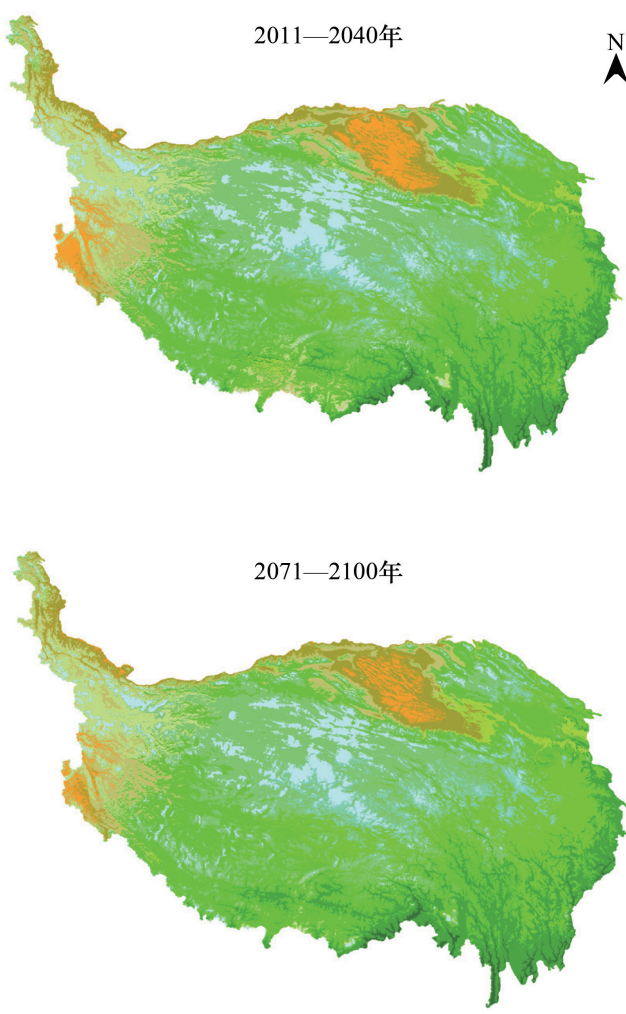

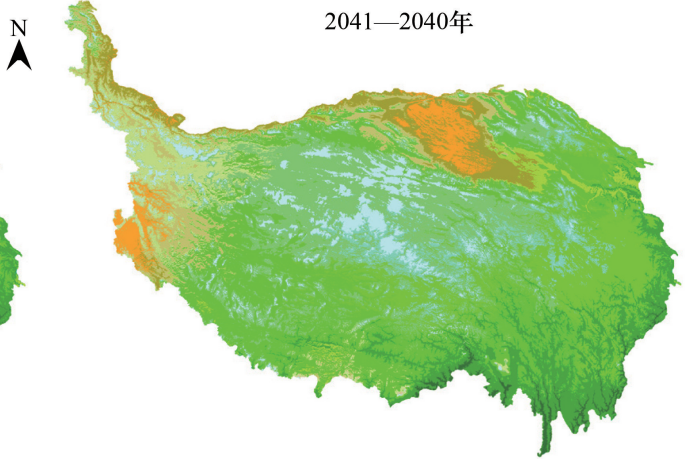

$0 \quad 500 \mathrm{~km}$

图 3 基于 RCP4.5 情景的青藏高原植被生态系统在 T1、T2 和 T3 三个时段的时空分布

Fig.3 Spatiotemporal distribution of vegetation ecosystem in Qinghai-Tibet Plateau under scenario RCP 4.5 during the three periods of T1, T2 and T3 
在 RCP8.5 情景下, 冰雪/冰原、高山湿润苔原和荒漠三种植被生态系统类型的面积持续减少最多,在 $\mathrm{T} 0$ - T3 时段平均每 10 年将分别减少 $4.034 \times 10^{4} \mathrm{~km}^{2} 、 2.498 \times 10^{4} \mathrm{~km}^{2}$ 和 $1.866 \times 10^{4} \mathrm{~km}^{2}$ 。山地湿润森林、亚高山 潮湿森林和山地灌丛三种植被生态系统类型面积的面积持续增加最多,在 $\mathrm{T} 0-\mathrm{T} 3$ 时段平均每 10 年将分别增 加 $5.179 \times 10^{4} \mathrm{~km}^{2} 、 5.153 \times 10^{4} \mathrm{~km}^{2}$ 和 $1.430 \times 10^{4} \mathrm{~km}^{2}$ 。从面积增加比例来看, 在 $\mathrm{T} 0$ - $\mathrm{T} 3$ 时段内, 亚高山潮湿森 林、山地灌丛、山地湿润森林、低山干旱森林、低山湿润森林面积的增长比率均大于 $290 \%$, 表明这几种植被生 态系统类型对气候变化响应的敏感性高于其它的植被生态系统类型。
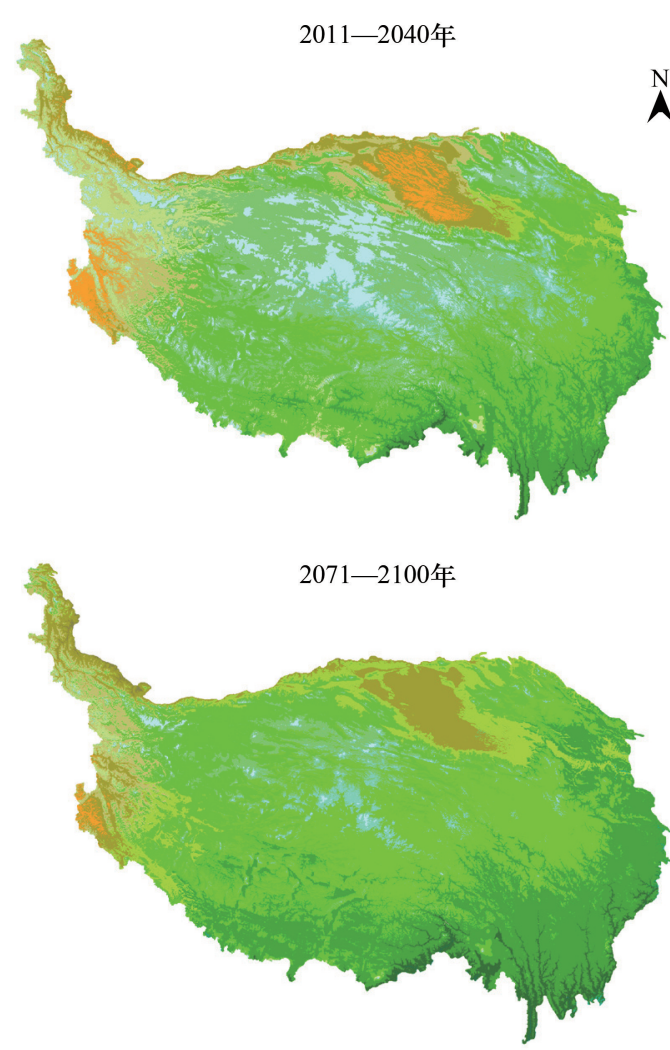

图 4 基于 RCP8.5 情景的青藏高原植被生态系统在 T1、T2 和 T3 三个时段的时空分布
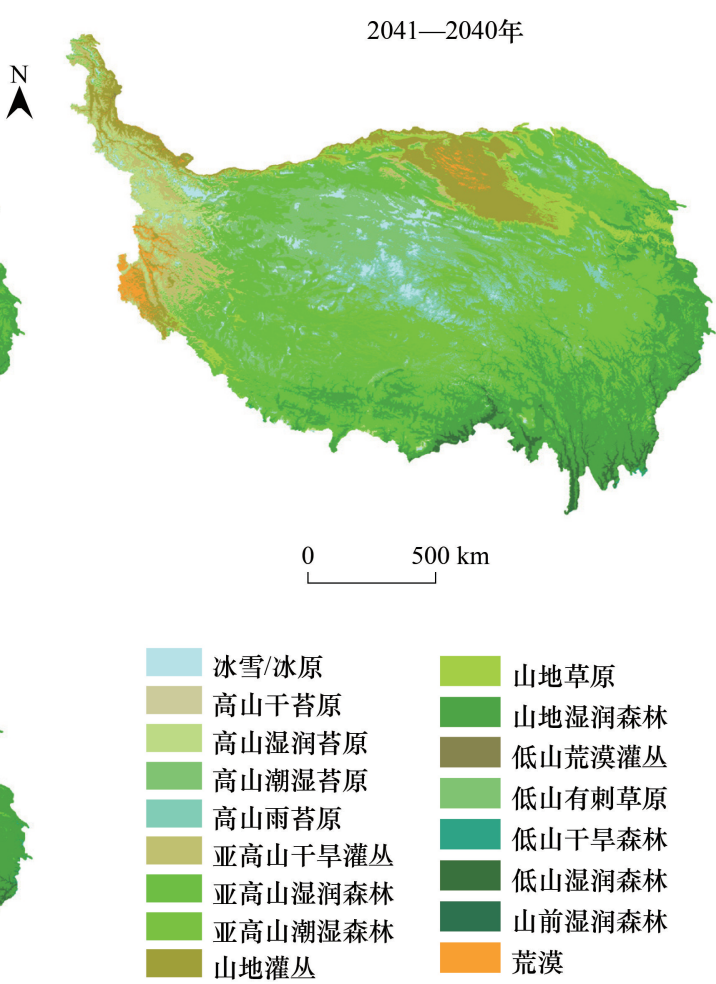

Fig.4 Spatiotemporal distribution of vegetation ecosystem in Qinghai-Tibet Plateau under scenario RCP8.5 during the three periods of T1, T2 and T3

2.3 植被生态系统类型多样性及斑块连通性分析

对青藏高原植被生态系统的生态多样性及斑块连通性的模拟结果 (表 1) 表明: 在未来气候变化驱动下, 青藏高原植被生态系的生态多样性整体上呈减少趋势, 斑块连通性则呈持续减少趋势。其中, RCP8.5 情景下 的生态多样性呈持续减少趋势, 在 T0-T3 时段内平均每 10 年将减少 $0.227 \%$; RCP2.6 和 RCP4.5 情景下的生 态多样性呈波动减少趋势,在 T0-T3 时段内平均每 10 年将分别减少 $0.056 \%$ 和 $0.041 \%$; RCP2.6、RCP4.5 和 RCP8.5 三种情景下的青藏高原植被生态系统斑块连通性均呈持续减少趋势, 其平均每 10 年将分别减少 $0.225 \% 、 0.226 \%$ 和 $0.419 \%$ 。这一研究结果显示,未来气候变化将导致青藏高原植被生态系统的生态多样性 和斑块连通性的整体呈减少趋势, 且气候变化越快( RCP8.5), 其生态多样性和斑块连通性减少速度越快。这 意味着未来气候变化强度将直接影响青藏高原植被生态系统生态多样性和斑块连通性的变化趋势和强度。

2.4 青藏高原植被生态系统平均中心的时空偏移情景

运用生态系统平均中心时空分析模型对青藏高原植被生态系统平均中心的时空偏移情景进行模拟的分 析结果 (表 2-4, 图 5) 表明, 在 RCP2.6、RCP4.5 和 RCP8.5 三种情景的驱动下, 青藏高原不同植被生态系统的 平均中心将呈现出不同的时空偏移趋势。 
表 1 青藏高原植被生态系统生态多样性及斑块连通性

Table 1 Ecological diversity and patch connectivity index of vegetation ecosystem in Qinghai-Tibet Plateau

\begin{tabular}{|c|c|c|c|}
\hline $\begin{array}{c}\text { 情景 } \\
\text { Scenario }\end{array}$ & $\begin{array}{c}\text { 研究时段 } \\
\text { Period }\end{array}$ & $\begin{array}{c}\text { 斑块连通性 } \\
\text { Patch connectivity }\end{array}$ & $\begin{array}{c}\text { 生态多样性 } \\
\text { Ecological diversity }\end{array}$ \\
\hline \multirow[t]{5}{*}{ RCP2.6 } & T0 & 0.099 & 0.247 \\
\hline & $\mathrm{T} 1$ & 0.081 & 0.247 \\
\hline & $\mathrm{T} 2$ & 0.080 & 0.249 \\
\hline & $\mathrm{T} 3$ & 0.078 & 0.242 \\
\hline & $\mathrm{T} 0$ - $\mathrm{T} 3$ 每 10 年的增加比例 $/ \%$ & -0.225 & -0.056 \\
\hline \multirow[t]{5}{*}{ RCP4.5 } & T0 & 0.099 & 0.247 \\
\hline & $\mathrm{T} 1$ & 0.081 & 0.244 \\
\hline & $\mathrm{T} 2$ & 0.078 & 0.249 \\
\hline & $\mathrm{T} 3$ & 0.078 & 0.244 \\
\hline & $\mathrm{T} 0$ - $\mathrm{T} 3$ 每 10 年的增加比例 $/ \%$ & -0.226 & -0.041 \\
\hline \multirow[t]{5}{*}{ RCP8.5 } & T0 & 0.099 & 0.247 \\
\hline & $\mathrm{T} 1$ & 0.078 & 0.243 \\
\hline & $\mathrm{T} 2$ & 0.076 & 0.242 \\
\hline & $\mathrm{T} 3$ & 0.061 & 0.227 \\
\hline & $\mathrm{T} 0$ - $\mathrm{T} 3$ 每 10 年的增加比例 $/ \%$ & -0.419 & -0.227 \\
\hline
\end{tabular}

RCP( Representative Concentration Pathway) 2.6,RCP4.5 和 RCP8.5 分别三种不同的代表性浓度途径;T0、T1、T2 和 T3 分别代表 1981一2010、 $2011-2040 、 2041-2070$ 和 $2071-2100$ 四个时段

在 RCP2.6 情景下 (表 2,图 5), 低山荒漠灌丛的平均中心在 T1-T2 时段将向东偏移 $0.158 \mathrm{~km}$, 然后在 $\mathrm{T} 2$ - $\mathrm{T} 3$ 时段,其平均中心将转向南偏移 $0.542 \mathrm{~km}$ 。高山干苔原平均中心的偏移幅度最大,其在 $\mathrm{T} 0$ - $\mathrm{T} 1$ 时段 将向东北为偏移 $4.974 \mathrm{~km}$, 在 $\mathrm{T} 1-\mathrm{T} 2$ 时段转向西南偏移 $2.199 \mathrm{~km}$, 在 $\mathrm{T} 2-\mathrm{T} 3$ 时段继续向西南偏移 2.351 $\mathrm{km}_{0}$ 。山地湿润森林的平均中心在 $\mathrm{T} 0$ - $\mathrm{T} 3$ 时段内将持续向西南方向偏移。冰雪/冰原、高山湿润苔原、高山潮 湿苔原、亚高山湿润森林和亚高山潮湿森林等植被生态系统类型的平均中心在 $\mathrm{T} 0-\mathrm{T} 3$ 时段内将整体呈向西 南偏移趋势。低山干旱森林的平均中心偏移距离最大, 在 T0-T3 时段内平均每 10 年将偏移 $1.33 \mathrm{~km} 。$ 低山 湿润森林的平均中心偏移距离最小, 在 T0-T3 时段内平均每 10 年仅偏移 $0.05 \mathrm{~km}$ 。在 RCP 2.6 情景下, 青藏 高原所有植被生态系统类型的平均中心在 $\mathrm{T} 0-\mathrm{T} 3$ 时段内平均每 10 年的偏移距为 $0.38 \mathrm{~km}$ 。

表 2 RCP 2.6 情景下青藏高原植被生态系统平均中心的偏移趋势

Table 2 Shift trends of mean center in potential vegetation ecosystems under RCP 2.6 in Qinghai-Tibet Plateau

\begin{tabular}{|c|c|c|c|c|c|c|}
\hline \multirow[b]{2}{*}{ 类型 Type } & \multicolumn{2}{|c|}{$\mathrm{T} 0-\mathrm{T} 1$} & \multicolumn{2}{|c|}{$\mathrm{T} 1-\mathrm{T} 2$} & \multicolumn{2}{|c|}{$\mathrm{T} 1-\mathrm{T} 3$} \\
\hline & $\begin{array}{c}\text { 偏移距离 } \\
\text { Shift } \\
\text { distance/km }\end{array}$ & $\begin{array}{c}\text { 偏移方向 } \\
\text { Shift } \\
\text { direction }\end{array}$ & $\begin{array}{c}\text { 偏移距离 } \\
\text { Shift } \\
\text { distance/km }\end{array}$ & $\begin{array}{c}\text { 偏移方向 } \\
\text { Shift } \\
\text { direction }\end{array}$ & $\begin{array}{c}\text { 偏移距离 } \\
\text { Shift } \\
\text { distance/km }\end{array}$ & $\begin{array}{c}\text { 偏移方向 } \\
\text { Shift } \\
\text { direction }\end{array}$ \\
\hline 冰雪/冰原 Ice/snow & 1.071 & 西南 & 0.28 & 南 & 0.124 & 西南 \\
\hline 高山干苔原 Alpine dry tundra & 4.974 & 东北 & 2.199 & 西南 & 2.351 & 西南 \\
\hline 高山湿润苔原 Alpine moist tundra & 2.079 & 南 & 0.782 & 西南 & 0.633 & 南 \\
\hline 高山潮湿苔原 Alpine wet tundra & 0.924 & 西南 & 0.38 & 南 & 0.092 & 西南 \\
\hline 高山雨苔原 Alpine rain tundra & 1.694 & 南 & 0.42 & 西 & 0.098 & 东北 \\
\hline 亚高山干旱灌丛 Subalpine arid shrub & 1.162 & 西 & 0.644 & 西南 & 0.343 & 西南 \\
\hline 亚高山湿润森林 Subalpine moist forest & 1.795 & 西南 & 1.142 & 南 & 0.255 & 南 \\
\hline 亚高山潮湿森林 Subalpine wet forest & 1.395 & 西南 & 0.767 & 西 & 0.143 & 西南 \\
\hline 山地灌丛 Mountain shrub & 0.669 & 东北 & 0.139 & 西南 & 0.127 & 东 \\
\hline 山地草原 Mountain grassland & 2.808 & 东北 & 0.732 & 西南 & 2.038 & 东北 \\
\hline 山地湿润森林 Mountain moist forest & 0.4 & 西南 & 0.317 & 西南 & 0.291 & 西南 \\
\hline 低山荒漠灌丛 Low mountain desert shrub & & & 0.158 & 东 & 0.542 & 南 \\
\hline 低山干旱森林 Low mountain arid forest & 0.927 & 东北 & 2.182 & 西 & 8.854 & 西 \\
\hline 低山湿润森林 Low mountain moist forest & 0.118 & 东北 & 0.202 & 东北 & 0.151 & 南 \\
\hline 山前湿润森林 Piedmont moist forest & 0.55 & 西南 & 0.893 & 西南 & 0.193 & 东北 \\
\hline 荒漠 Desert & 5.604 & 西南 & 0.58 & 西南 & 0.2 & 东北 \\
\hline
\end{tabular}



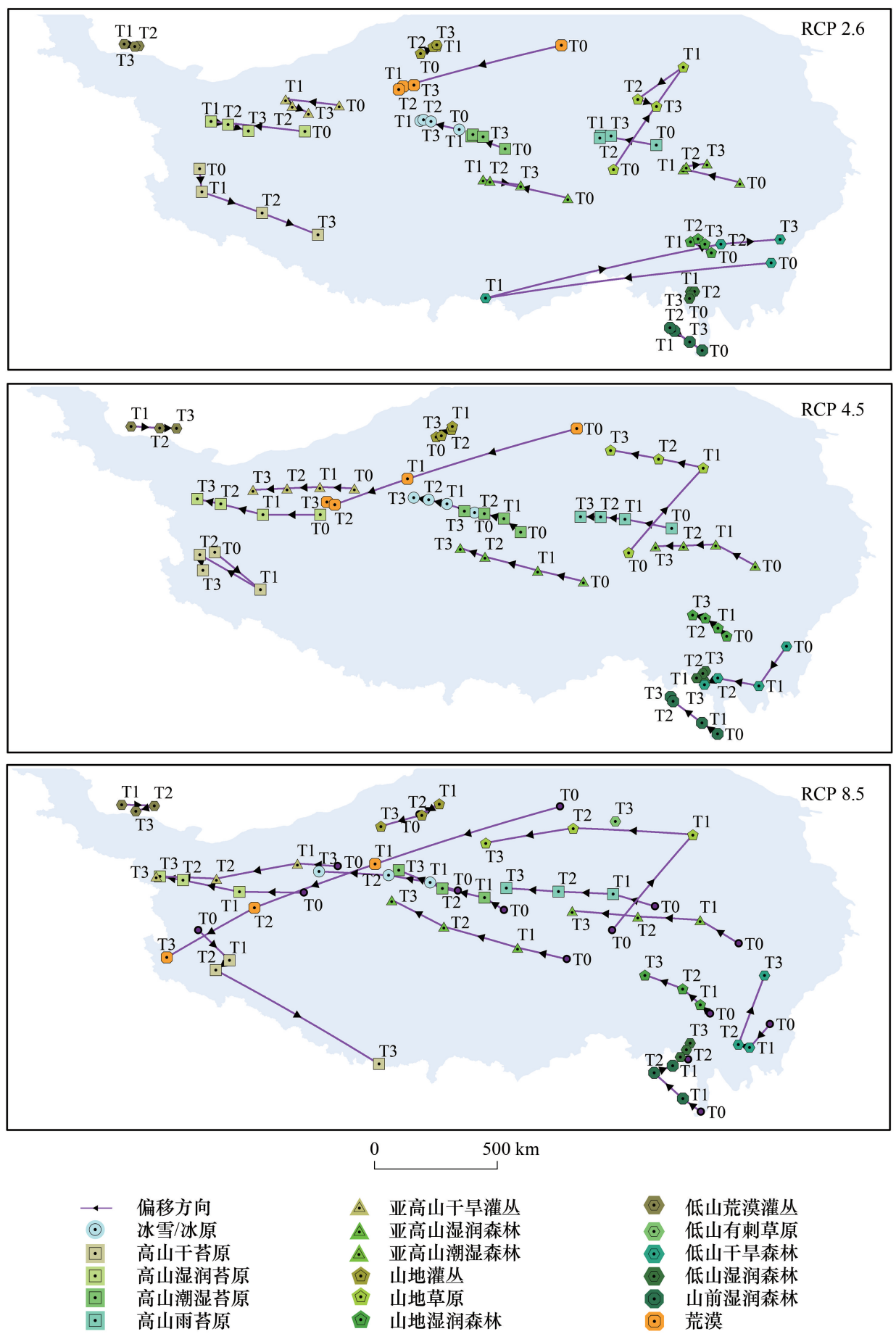

图 5 三种情景下青藏高原植被生态系统平均中心的时空偏移

Fig.5 Shift trends of mean center in every vegetation ecosystem of Qinghai-Tibet Plateau under the three scenarios

RCP (Representative Concentration Pathway) 2.6,RCP4.5 和 RCP8.5 分别三种不同的代表性浓度途径; T0 代表: $1981-2010$ 年时段

在 RCP4.5 情景下 (表 3, 图 5), 低山荒漠灌丛植被生态系统仅出现在 T1-T3 段出现, 其平均中心将向持 续向北分别偏移 $1.053 \mathrm{~km}$ 和 $0.617 \mathrm{~km}$ 。亚高山干旱灌丛、亚高山潮湿森林以和山地草原三种植被生态系统 的平均中心偏移距离大于其它的生态系统类型。高山湿润苔原和高山雨苔原的平均中心在 $\mathrm{T} 0-\mathrm{T} 3$ 时段将 持续向南偏移,而山地湿润森林和荒漠生态系统的平均中心在 $\mathrm{T} 0-\mathrm{T} 3$ 时段将持续向西南方向偏移。冰雪/ 冰原、亚高山湿润森林和山地湿润森林的平均中心在 $\mathrm{T} 0$ - $\mathrm{T} 3$ 时段将整体向西南方向偏移。低山湿润森林的 
平均中心偏移距离最小,在 $\mathrm{T} 0-\mathrm{T} 1$ 时段内向西南偏移 $0.329 \mathrm{~km}$, 继而在 $\mathrm{T} 1-\mathrm{T} 2$ 时段转向东北方向偏移 $0.286 \mathrm{~km}$,在 $\mathrm{T} 2-\mathrm{T} 3$ 时段则继续向东北方向偏移 $0.138 \mathrm{~km}$ 。

表 3 RCP 4.5 情景下青藏高原各种植被生态系统平均中心的偏移趋势

Table 3 Shift trends of mean center in potential vegetation ecosystems under RCP 4.5 in Qinghai-Tibet Plateau

\begin{tabular}{|c|c|c|c|c|c|c|}
\hline \multirow[b]{2}{*}{ 类型 Type } & \multicolumn{2}{|c|}{ T0-T1 } & \multicolumn{2}{|c|}{$\mathrm{T} 1-\mathrm{T} 2$} & \multicolumn{2}{|c|}{$\mathrm{T} 1-\mathrm{T} 3$} \\
\hline & $\begin{array}{c}\text { 偏移距离 } \\
\text { Shift } \\
\text { distance/km }\end{array}$ & $\begin{array}{c}\text { 偏移方向 } \\
\text { Shift } \\
\text { direction }\end{array}$ & $\begin{array}{c}\text { 偏移距离 } \\
\text { Shift } \\
\text { distance/km }\end{array}$ & $\begin{array}{c}\text { 偏移方向 } \\
\text { Shift } \\
\text { direction }\end{array}$ & $\begin{array}{c}\text { 偏移距离 } \\
\text { Shift } \\
\text { distance/km }\end{array}$ & $\begin{array}{c}\text { 偏移方向 } \\
\text { Shift } \\
\text { direction }\end{array}$ \\
\hline 冰雪/冰原 Ice/snow & 1.067 & 西南 & 0.678 & 南 & 0.557 & 南 \\
\hline 高山干苔原 Alpine dry tundra & 2.165 & 东北 & 2.561 & 西南 & 0.575 & 东 \\
\hline 高山湿润苔原 Alpine moist tundra & 2.107 & 南 & 1.592 & 南 & 0.882 & 南 \\
\hline 高山潮湿苔原 Alpine wet tundra & 0.786 & 西南 & 0.741 & 南 & 0.737 & 南 \\
\hline 高山雨苔原 Alpine rain tundra & 1.744 & 南 & 0.903 & 南 & 0.736 & 南 \\
\hline 亚高山干旱灌丛 Subalpine arid shrub & 1.27 & 南 & 1.202 & 西 & 1.251 & 西 \\
\hline 亚高山湿润森林 Subalpine moist forest & 1.713 & 南 & 2.007 & 南 & 0.963 & 西南 \\
\hline 亚高山潮湿森林 Subalpine wet forest & 1.642 & 西南 & 1.189 & 西 & 1.034 & 西 \\
\hline 山地灌丛 Mountain shrub & 0.715 & 东北 & 0.126 & 南 & 0.43 & 西南 \\
\hline 山地草原 Mountain grassland & 4.141 & 东北 & 1.668 & 南 & 1.794 & 南 \\
\hline 山地湿润森林 Mountain moist forest & 0.435 & 西南 & 0.588 & 西南 & 0.483 & 南 \\
\hline 低山荒漠灌丛 Low mountain desert shrub & & & 1.053 & 西北 & 0.617 & 北 \\
\hline 低山干旱森林 Low mountain arid forest & 1.775 & 西南 & 1.528 & 南 & 0.536 & 西南 \\
\hline 低山湿润森林 Low mountain moist forest & 0.329 & 西南 & 0.286 & 东北 & 0.138 & 东北 \\
\hline 山前湿润森林 Piedmont moist forest & 0.695 & 西南 & 1.322 & 西南 & 0.188 & 西南 \\
\hline 荒漠 Desert & 6.47 & 西南 & 2.838 & 西南 & 0.295 & 西南 \\
\hline
\end{tabular}

在 RCP8.5 情景下 (表 4,图 5), 低山荒漠灌丛从 $\mathrm{T} 1$ 时段开始出现,其平均中心在 $\mathrm{T} 1-\mathrm{T} 3$ 时段内先向西 北偏移 $1.197 \mathrm{~km}$, 然后转向西南偏移 $0.713 \mathrm{~km}$ 。青藏高原高山湿润苔原、山地草原和荒漠生态系统类型的平 均中心偏移强度高于其它的植被生态系统类型,在 $\mathrm{T} 1$ - $\mathrm{T} 3$ 时段内平均每 10 年将分别偏移 $1.012 \mathrm{~km} 、 1.361 \mathrm{~km}$ 和 $1.724 \mathrm{~km}$ 。山地湿润森林和荒漠生态系统类型的平均中心在 $\mathrm{T} 1-\mathrm{T} 3$ 时段内将持续向西南方向偏移。冰 雪/冰原、高山干苔原、高山苔原、亚高山湿润森林和山地灌丛等植被生态系统类型的平均中心将整体上向西 南方向偏移。低山湿润森林的平均中心偏移强度最小,在 $\mathrm{T} 1-\mathrm{T} 3$ 时段内平均每 10 年仅偏移 $0.105 \mathrm{~km}$ 。

2.5 青藏高原不同海拔植被生态系统变化情景

为了更好地分析不同海拔高度上青藏高原植被生态系统在不同气候情景驱动下的变化特征,结合青藏高 原植被生态系统情景模拟结果，以 1000m 海拔高程差为间隔, 分别对 RCP2.6、RCP4.5 和 RCP8.5 三种情景下 的青藏高原不同海拔上植被生态系统变化情况进行空间统计和对比分析 (表 5)显示: 在青藏高原所有的海 拔高度带上, RCP8.5 情景下的植被生态系统的变化强度最大, 在 RCP4.5 情景下次之, RCP2.6 情景下变化强 度最小。在 RCP2.6、RCP4.5 和 RCP 8.5 三种情景下,青藏高原海拔大于 $8000 \mathrm{~m}$ 的植被生态系统变化强度整 体上均高于其它海拔高度带上的植被生态系统变化强度, 在 $\mathrm{T} 0$ - $\mathrm{T} 3$ 时段内三种情景下每 10 年的变化面积分 别占该梯度总面积的 7.41\%、7.41\% 和 $18.52 \%$ 。另外,在 RCP2.6 和 RCP4.5 两种情景下分布于青藏高原海拔 小于 $1000 \mathrm{~m}$ 的植被生态系统变化最为缓慢,在 $\mathrm{T} 0-\mathrm{T} 3$ 时段内三种情景下每 10 年的变化面积分别占该梯度 总面积的 $1.64 \%$ 和 $5.08 \%$ 。在 RCP45 情景下, 分布于青藏高原海拔 $1000-2000 \mathrm{~m}$ 之间的植被生态系统变化 最为缓慢,在 $\mathrm{T} 0$ - $\mathrm{T} 3$ 时段内每 10 年的变化面积占该梯度总面积的 $2.68 \%$ 。总之,在三种情景下,青藏高原的 植被生态系统变化强度从低海拔到高海拔区域整体呈上升趋势。 
表 4 RCP 8.5 情景下青藏高原各种植被生态系统平均中心的偏移趋势

Table 4 Shift trends of mean center in potential vegetation ecosystems under RCP 8.5 in Qinghai-Tibet Plateau

\begin{tabular}{|c|c|c|c|c|c|c|}
\hline \multirow[b]{2}{*}{ 类型 Type } & \multicolumn{2}{|c|}{$\mathrm{T} 0-\mathrm{T} 1$} & \multicolumn{2}{|c|}{$\mathrm{T} 1-\mathrm{T} 2$} & \multicolumn{2}{|c|}{$\mathrm{T} 1-\mathrm{T} 3$} \\
\hline & $\begin{array}{c}\text { 偏移距离 } \\
\text { Shift } \\
\text { distance/km }\end{array}$ & $\begin{array}{c}\text { 偏移方向 } \\
\text { Shift } \\
\text { direction }\end{array}$ & $\begin{array}{c}\text { 偏移距离 } \\
\text { Shift } \\
\text { distance/km }\end{array}$ & $\begin{array}{c}\text { 偏移方向 } \\
\text { Shift } \\
\text { direction }\end{array}$ & $\begin{array}{c}\text { 偏移距离 } \\
\text { Shift } \\
\text { distance/km }\end{array}$ & $\begin{array}{c}\text { 偏移方向 } \\
\text { Shift } \\
\text { direction }\end{array}$ \\
\hline 冰雪/冰原 Ice/snow & 1.069 & 西南 & 1.549 & 南 & 2.555 & 南 \\
\hline 高山干苔原 Alpine dry tundra & 1.589 & 东北 & 0.615 & 西南 & 6.908 & 东北 \\
\hline 高山湿润苔原 Alpine moist tundra & 2.366 & 南 & 2.121 & 南 & 0.846 & 南 \\
\hline 高山潮湿苔原 Alpine wet tundra & 0.857 & 西南 & 1.575 & 南 & 1.736 & 西南 \\
\hline 高山雨苔原 Alpine rain tundra & 1.614 & 西南 & 2.007 & 南 & 1.914 & 南 \\
\hline 亚高山干旱灌丛 Subalpine arid shrub & 1.495 & 南 & 3.027 & 西 & 2.2 & 南 \\
\hline 亚高山湿润森林 Subalpine moist forest & 1.856 & 南 & 2.818 & 西南 & 2.139 & 西南 \\
\hline 亚高山潮湿森林 Subalpine wet forest & 1.666 & 西南 & 2.284 & 南 & 2.421 & 南 \\
\hline 山地灌丛 Mountain shrub & 0.824 & 东北 & 0.758 & 西南 & 1.569 & 西南 \\
\hline 山地草原 Mountain grassland & 4.592 & 东北 & 4.401 & 南 & 3.252 & 西 \\
\hline 山地湿润森林 Mountain moist forest & 0.494 & 西南 & 0.878 & 西南 & 1.469 & 西南 \\
\hline 低山荒漠灌丛 Low mountain desert shrub & & & 1.197 & 西北 & 0.713 & 西南 \\
\hline 低山干旱森林 Low mountain arid forest & 1.14 & 西南 & 0.431 & 南 & 2.717 & 东北 \\
\hline 低山湿润森林 Low mountain moist forest & 0.311 & 西南 & 0.348 & 东北 & 0.284 & 东北 \\
\hline 山前湿润森林 Piedmont moist forest & 0.824 & 西南 & 1.412 & 西南 & 0.73 & 东北 \\
\hline 荒漠 Desert & 7.117 & 西南 & 4.705 & 西南 & 3.697 & 西南 \\
\hline
\end{tabular}

表 5 青藏高原不同海拔上的植被生态系统变化情景

Table 5 Change scenarios of vegetation distribution changes in different elevations of Qinghai-Tibet Plateau

\begin{tabular}{|c|c|c|c|c|c|c|c|}
\hline \multirow[b]{2}{*}{$\begin{array}{l}\text { 高度带/m } \\
\text { Elevation belt }\end{array}$} & \multirow[b]{2}{*}{$\begin{array}{l}\text { 时段 } \\
\text { Period }\end{array}$} & \multicolumn{2}{|c|}{ RCP2.6 } & \multicolumn{2}{|c|}{ RCP4.5 } & \multicolumn{2}{|c|}{ RCP85 } \\
\hline & & $\begin{array}{c}\text { 变化面积 } \\
\text { Change area/ } \\
10^{4} \mathrm{~km}^{2}\end{array}$ & $\begin{array}{c}\text { 比例 } \\
\text { Ratio/\% }\end{array}$ & $\begin{array}{c}\text { 变化面积 } \\
\text { Change area/ } \\
10^{4} \mathrm{~km}^{2}\end{array}$ & $\begin{array}{c}\text { 比例 } \\
\text { Ratio/\% }\end{array}$ & $\begin{array}{c}\text { 变化面积 } \\
\text { Change area/ } \\
10^{4} \mathrm{~km}^{2}\end{array}$ & $\begin{array}{c}\text { 比例 } \\
\text { Ratio/\% }\end{array}$ \\
\hline \multirow[t]{4}{*}{$<1000$} & $\mathrm{~T} 0-\mathrm{T} 1$ & 0.00 & 2.55 & 0.00 & 3.31 & 0.00 & 4.58 \\
\hline & $\mathrm{T} 1-\mathrm{T} 2$ & 0.00 & 9.67 & 0.01 & 25.70 & 0.02 & 52.67 \\
\hline & $\mathrm{T} 2-\mathrm{T} 3$ & 0.00 & 2.55 & 0.01 & 19.59 & 0.02 & 39.95 \\
\hline & $\mathrm{T} 0$ - $\mathrm{T} 3$ 每 10 年的变化 & 0.00 & 1.64 & 0.00 & 5.40 & 0.00 & 10.80 \\
\hline \multirow[t]{4}{*}{$1000-2000$} & $\mathrm{~T} 0-\mathrm{T} 1$ & 0.12 & 12.26 & 0.09 & 9.46 & 0.10 & 10.22 \\
\hline & $\mathrm{T} 1-\mathrm{T} 2$ & 0.07 & 6.76 & 0.11 & 11.08 & 0.13 & 13.58 \\
\hline & $\mathrm{T} 2-\mathrm{T} 3$ & 0.01 & 1.19 & 0.04 & 3.58 & 0.35 & 35.80 \\
\hline & $\mathrm{T} 0-\mathrm{T} 3$ 每 10 年的变化 & 0.02 & 2.24 & 0.03 & 2.68 & 0.06 & 6.62 \\
\hline \multirow[t]{4}{*}{$2000-3000$} & $\mathrm{~T} 0-\mathrm{T} 1$ & 4.36 & 22.46 & 4.51 & 23.24 & 5.58 & 28.73 \\
\hline & $\mathrm{T} 1-\mathrm{T} 2$ & 0.75 & 3.89 & 3.11 & 16.03 & 4.99 & 25.71 \\
\hline & $\mathrm{T} 2-\mathrm{T} 3$ & 1.64 & 8.43 & 1.96 & 10.09 & 2.07 & 10.64 \\
\hline & $\mathrm{T} 0$ - $\mathrm{T} 3$ 每 10 年的变化 & 0.75 & 3.86 & 1.07 & 5.49 & 1.40 & 7.23 \\
\hline \multirow[t]{4}{*}{$3000-4000$} & $\mathrm{~T} 0-\mathrm{T} 1$ & 7.86 & 15.01 & 8.13 & 15.53 & 8.47 & 16.19 \\
\hline & $\mathrm{T} 1-\mathrm{T} 2$ & 3.36 & 6.41 & 5.74 & 10.98 & 10.96 & 20.95 \\
\hline & $\mathrm{T} 2-\mathrm{T} 3$ & 0.78 & 1.50 & 3.09 & 5.90 & 11.83 & 22.60 \\
\hline & $\mathrm{T} 0$ - $\mathrm{T} 3$ 每 10 年的变化 & 1.33 & 2.55 & 1.88 & 3.60 & 3.47 & 6.64 \\
\hline \multirow[t]{4}{*}{$4000-5000$} & $\mathrm{~T} 0-\mathrm{T} 1$ & 21.52 & 15.97 & 22.83 & 16.94 & 23.55 & 17.47 \\
\hline & $\mathrm{T} 1-\mathrm{T} 2$ & 11.56 & 8.57 & 23.58 & 17.50 & 36.47 & 27.06 \\
\hline & $\mathrm{T} 2-\mathrm{T} 3$ & 3.76 & 2.79 & 12.80 & 9.50 & 35.01 & 25.98 \\
\hline & $\mathrm{T} 0-\mathrm{T} 3$ 每 10 年的变化 & 4.09 & 3.04 & 6.58 & 4.88 & 10.56 & 7.84 \\
\hline
\end{tabular}




\begin{tabular}{|c|c|c|c|c|c|c|c|}
\hline \multirow[b]{2}{*}{$\begin{array}{l}\text { 高度带/m } \\
\text { Elevation belt }\end{array}$} & \multirow[b]{2}{*}{$\begin{array}{l}\text { 时段 } \\
\text { Period }\end{array}$} & \multicolumn{2}{|c|}{ RCP2.6 } & \multicolumn{2}{|c|}{ RCP4.5 } & \multicolumn{2}{|c|}{ RCP85 } \\
\hline & & $\begin{array}{c}\text { 变化面积 } \\
\text { Change area/ } \\
10^{4} \mathrm{~km}^{2}\end{array}$ & $\begin{array}{c}\text { 比例 } \\
\text { Ratio/\% }\end{array}$ & $\begin{array}{c}\text { 变化面积 } \\
\text { Change area/ } \\
10^{4} \mathrm{~km}^{2}\end{array}$ & $\begin{array}{c}\text { 比例 } \\
\text { Ratio/\% }\end{array}$ & $\begin{array}{c}\text { 变化面积 } \\
\text { Change area/ } \\
10^{4} \mathrm{~km}^{2}\end{array}$ & $\begin{array}{c}\text { 比例 } \\
\text { Ratio/\% }\end{array}$ \\
\hline \multirow[t]{4}{*}{$5000-6000$} & $\mathrm{~T} 0-\mathrm{T} 1$ & 12.58 & 19.82 & 13.48 & 21.24 & 13.71 & 21.61 \\
\hline & $\mathrm{T} 1-\mathrm{T} 2$ & 4.47 & 7.04 & 9.66 & 15.23 & 16.71 & 26.33 \\
\hline & $\mathrm{T} 2-\mathrm{T} 3$ & 2.62 & 4.13 & 5.60 & 8.83 & 19.38 & 30.54 \\
\hline & $\mathrm{T} 0$ - $\mathrm{T} 3$ 每 10 年的变化 & 2.19 & 3.44 & 3.19 & 5.03 & 5.53 & 8.72 \\
\hline \multirow[t]{4}{*}{$6000-7000$} & $\mathrm{~T} 0-\mathrm{T} 1$ & 0.11 & 10.43 & 0.12 & 11.28 & 0.11 & 10.78 \\
\hline & $\mathrm{T} 1-\mathrm{T} 2$ & 0.05 & 4.29 & 0.12 & 11.51 & 0.20 & 18.68 \\
\hline & $\mathrm{T} 2-\mathrm{T} 3$ & 0.05 & 4.39 & 0.07 & 6.51 & 0.24 & 22.97 \\
\hline & $\mathrm{T} 0$ - $\mathrm{T} 3$ 每 10 年的变化 & 0.02 & 2.12 & 0.03 & 3.26 & 0.06 & 5.83 \\
\hline \multirow[t]{4}{*}{$7000-8000$} & $\mathrm{~T} 0-\mathrm{T} 1$ & 0.00 & 20.21 & 0.00 & 24.47 & 0.00 & 21.28 \\
\hline & $\mathrm{T} 1-\mathrm{T} 2$ & 0.00 & 2.13 & 0.00 & 6.38 & 0.00 & 10.64 \\
\hline & $\mathrm{T} 2-\mathrm{T} 3$ & 0.00 & 5.32 & 0.00 & 10.64 & 0.00 & 13.83 \\
\hline & $\mathrm{T} 0$ - $\mathrm{T} 3$ 每 10 年的变化 & 0.00 & 3.07 & 0.00 & 4.61 & 0.00 & 5.08 \\
\hline \multirow[t]{4}{*}{$>8000$} & $\mathrm{~T} 0-\mathrm{T} 1$ & 0.00 & 66.67 & 0.00 & 66.67 & 0.00 & 66.67 \\
\hline & $\mathrm{T} 1-\mathrm{T} 2$ & 0.00 & 0.00 & 0.00 & 0.00 & 0.00 & 0.00 \\
\hline & $\mathrm{T} 2-\mathrm{T} 3$ & 0.00 & 0.00 & 0.00 & 0.00 & 0.00 & 100.00 \\
\hline & $\mathrm{T} 0$ - $\mathrm{T} 3$ 每 10 年的变化 & 0.00 & 7.41 & 0.00 & 7.41 & 0.00 & 18.52 \\
\hline
\end{tabular}

2.6 不同气候情景驱动下青藏高原植被生态系统变化的对比分析

在 RCP2.6、RCP4.5 和 RCP8.5 三种气候情景驱动下的青藏高原植被生态系统将呈现处不同的差异特征。 整体上表现为, 青藏高原植被生态系统在 RCP8.5 情景驱动下的面积变化、平均中心偏移、生态多样性变化及 不同海拔高度分布的变化强度整体上高于在 RCP2.6 和 RCP4.5 情景驱动下的变化情景。其中,冰雪/冰原和 荒漠两类生态系统类型的面积在三种情景下的 $\mathrm{T} 0-\mathrm{T} 3$ 时段内均呈持续减少趋势, 且 RCP8.5 情景下的减少 速度高于 RCP2.6 和 RCP4.5 情景下的减少速度; 三种情景下的青藏高原植被生态系统的生态多样性和斑块 连通性整体上呈减少趋势, RCP2.6 情景下的减少速度最慢, 而 RCP8.5 情景下的减少速度最快; 三种情景下的 冰雪/冰原、亚高山湿润森林和山地湿润森林的平均中心在 $\mathrm{T} 0-\mathrm{T} 3$ 时段均将向西南方向偏移,且在 RCP8.5 情景下的偏移幅度最大, RCP4.5 情景次之, RCP2.6 情景下的偏移幅度最小; 从青藏高原的低海拔到高海拔区 域,分布于不同海拔高度上的植被生态系统类型的变化强度呈逐渐提升趋势。

\section{3 讨论与结论}

该论文针对现有 HLZ 生态系统模型主要运用于从维度和经度二维的角度模拟和解释植被生态系统在不 同尺度上的变化情景 ${ }^{[17-18,26-28,30]}$, 而缺乏从垂直角度模拟植被生态系统情景变化的应用不足,结合气候观测 数据和气候情景数据, 从植被生态系统分布垂直地带性的角度, 实现了 RCP2.6、RCP4.5 和 RCP8.5 三种气候 情景驱动下的青藏高原植被生态系统垂直分布的时空变化情景模拟。结果显示,有效集成 DEM 数据的改进 型 HLZ 生态系统模型, 能够有效地对不同气候情景驱动下的青藏高原植被生态系统垂直分布带的时空分布 格局变化及未来情景进行模拟。

模拟结果表明,青藏高原共有 16 种植被生态系统类型,其中高山潮湿苔原、亚高山湿润森林和冰雪/冰原 为青藏高原主要的植被生态系统类型,分别占总面积的 $23.69 \% 、 17.79 \%$ 和 $14.78 \%$ 。在 T0-T3 期间, 青藏高 原的高山湿润苔原、高山干苔原、荒漠呈持续减少趋势, 平均每 10 年将分别减少 $1.96 \times 10^{4} \mathrm{~km}^{2} 、 0.15 \times 10^{4} \mathrm{~km}^{2}$ 和 $1.58 \times 10^{4} \mathrm{~km}^{2}$; 亚高山潮湿森林、山地湿润森林和山地灌丛呈持续增加趋势, 平均每 10 年将分别增加 $3.42 \times$ $10^{4} \mathrm{~km}^{2} 、 2.98 \times 10^{4} \mathrm{~km}^{2}$ 和 $1.19 \times 10^{4} \mathrm{~km}^{2}$; RCP8.5 情景下青藏高原的植被生态系统平均中心的偏移幅度最大， 
RCP4.5 情景下的偏移幅度次之, 而 RCP2.6 情景下的偏移幅度最小。另外, 在三种气候变化情景驱动下, 青藏 高原植被生态系统的生态多样性呈减少趋势。青藏高原区域内的高山干苔原、亚高山潮湿森林、山地灌丛、山 地湿润森林和荒漠等植被生态系统类型对气候变化的敏感性高于其它的植被生态系统类。总之,气候变化强 度将直接影响青藏高原植被生态系统的面积、平均中心及其生态多样性的时空变化幅度, 在 T0-T3 时段内, RCP8.5 情景下的变化幅度最大, 而 RCP2.6 情景下的变化幅度最小。气温和降水作为植被生态系统分布及其 多样性的直接驱动因子, 在未来气候变化情景下, 青藏高原植被生态系统在不同的垂直带上将呈现处不同的 差异。随着海拔的升高, 青藏高原植被生态系统空间分布的动态差异对气候变化的响应强度逐渐增大 ${ }^{[25,49] 。}$ 尤其是分布于青藏高原海拔 $8000 \mathrm{~m}$ 以上的植被生态系统类型对气候变化的响应最为敏感。

因此, 在青藏高原生态系统时空变化趋势及未来情景的综合评估, 及其对自然气候变化与人类活动耦合 驱动效应研究的过程中, 不仅要关注低海拔地区及荒漠化区域的生态系统效应分析, 而且需要更加关注高海 拔区域的生态系统的时空演化机理分析, 这对深入揭示气候变化对青藏高原生态系统的影响效应及驱动机 理, 以及如何部署青藏高原生态安全动态监测体系, 提升国家生态安全屏障的总体功能具有重要意义 ${ }^{[32]}$ 。

\section{参考文献( References) :}

[ 1 ] Thomas C D, Cameron A, Green R E, Bakkenes M, Beaumont L J, Collingham Y C, Erasmus B F N, de Siqueira M F, Grainger A, Hannah L, Hughes L, Huntley B, van Jaarsveld A S, Midgley G F, Miles L, Ortega-Huerta M A, Peterson A T, Phillips O L, Williams S E. Extinction risk from climate change. Nature, 2004, 427(6970): 145-148.

[ 2 ] 叶笃正, 符淙斌, 董文杰. 全球变化科学进展与未来趋势. 地球科学进展, 2002, 17(4) : 467-469.

[ 3 ] Zhu Z C, Piao S L, Myneni R B, Huang M T, Zeng Z Z, Canadell J G, Ciais P, Sitch S, Friedlingstein P, Arneth A, Cao C X, Cheng L, Kato E, Koven C, Li Y, Lian X, Liu Y W, Liu R G, Mao J F, Pan Y Z, Peng S S, Peñuelas J, Poulter B, Pugh T A M, Stocker B D, Viovy N, Wang X H, Wang Y P, Xiao Z Q, Yang H, Zaehle S, Zeng N. Greening of the Earth and its drivers. Nature Climate Change, 2016, 6( 8): $791-795$.

[ 4 ] 周广胜, 何奇瑾. 生态系统响应全球变化的陆地样带研究. 地球科学进展, 2012, 27(5): 563-572.

[5] 朴世龙, 张新平, 陈安平, 刘强, 连旭, 王旭辉, 彭书时, 吴秀臣. 极端气候事件对陆地生态系统碳循环的影响. 中国科学: 地球科学, $2019,49(9): 1321-1334$.

[ 6 ] 周广胜, 张新时. 植被对于气候的反馈作用. 植物学报, 1996, 38(1): 1-7.

[ 7 ] Betts R A, Cox P M, Woodward F I. Simulated responses of potential vegetation to doubled- $\mathrm{CO}_{2}$ climate change and feedbacks on near-surface temperature. Global Ecology \& Biogeography, 2000, 9(2): 171-180.

[ 8 ] 陈卓奇, 邵全琴, 刘纪远, 王军邦. 基于 MODIS 的青藏高原植被净初级生产力研究. 中国科学: 地球科学, 2012, 42(3): 402-410.

[ 9 ] 赵东升, 吴绍洪.气候变化情景下中国自然生态系统脆弱性研究. 地理学报, 2013, 68(5): 602-610.

[10] Leemans R, Eickhout B. Another reason for concern: regional and global impacts on ecosystems for different levels of climate change. Global Environmental Change, 2004, 14(3): 219-228.

[11] 焦珂伟, 高江波, 吴绍洪, 侯文娟. 植被活动对气候变化的响应过程研究进展. 生态学报, 2018, 38(6): 2229-2238.

[12] 于贵瑞, 李文华, 邵明安, 张扬建, 王绍强, 牛书丽, 何洪林, 戴尔阜, 李发东, 马泽清. 生态系统科学研究与生态系统管理. 地理学报, 2020, 75(12): 2620-2635.

[13] Pielke R A, Avissar R, Raupach M, Dolman A J, Zeng X B, Denning A S. Interactions between the atmosphere and terrestrial ecosystems: influence on weather and climate. Global Change Biology, 1998, 4(5): 461-475.

[14] Mayle F E, Beerling D J, Gosling W D, Bush M B. Responses of Amazonian ecosystems to climatic and atmospheric carbon dioxide changes since the last glacial maximum. Philosophical Transactions of the Royal Society of London. Series B, Biological Sciences, 2004, 359(1443) : 499-514.

[15] Biermann F. 'Earth system governance' as a crosscutting theme of global change research. Global Environmental Change, 2007, 17 (3/4): 326-337.

[16] 岳天祥, 范泽孟. 典型陆地生态系统对气候变化响应的定量研究. 科学通报, 2014, 59(3): 217-231.

[17] Zhou G S, Wang Y H. Global change and climate-vegetation classification. Chinese Science Bulletin, 2000, 45(7) : 577-585.

[18] Yue T X, Fan Z M, Liu J Y. Changes of major terrestrial ecosystems in China since 1960. Global and Planetary Change, 2005, 48 (4) : $287-302$.

[19] Box E O. Predicting physiognomic vegetation types with climate variables. Vegetatio, 1981, 45(2) : 127-139.

[20] VEMAP Members. Vegetation/Ecosystem Modeling and Analysis Project: comparing biogeography and biogeochemistry models in a continental-scale 
study of terrestrial ecosystem responses to climate change and $\mathrm{CO}_{2}$ doubling. Global Biogeochemical Cycles, 1995 , 9(4) : 407-437.

[21] Neilson R P, King G A, Koerper G. Toward a rule-based biome model. Landscape Ecology, 1992, 7(1): $27-43$.

[22] Foley J A, Prentice I C, Ramankutty N, Levis S, Pollard D, Sitch S, Haxeltine A. An integrated biosphere model of land surface processes, terrestrial carbon balance, and vegetation dynamics. Global Biogeochemical Cycles, 1996, 10(4): 603-628.

[23] Quillet A, Peng C H, Garneau M. Toward dynamic global vegetation models for simulating vegetation-climate interactions and feedbacks: recent developments, limitations, and future challenges. Environmental Reviews, 2010, 18: 333-353.

[24］李婧, 范泽孟, 岳天祥. 中国西南地区土地覆盖情景的时空模拟. 生态学报, 2014, 34(12): 3266-3275.

[25］范泽孟, 范斌. 欧亚大陆植被生态系统平均中心时空偏移的情景模拟. 生态学报, 2019, 39(14): 5028-5039.

[26] Yue T X, Fan Z M, Chen C F, Sun X F, Li B L. Surface modelling of global terrestrial ecosystems under three climate change scenarios. Ecological Modelling, 2011, 222(14): 2342-2361.

[27] Fan Z M, Fan B, Yue T X. Terrestrial ecosystem scenarios and their response to climate change in Eurasia. Science China Earth Sciences, 2019, $62(10): 1607-1618$.

[28] Fan Z M, Bai R Y, Yue T X. Scenarios of land cover in Eurasia under climate change. Journal of Geographical Sciences, 2020 , 30 ( 1) : 3-17.

[29] Post W M, Emanuel W R, Zinke P J, Stangenberger A G. Soil carbon pools and world life zones. Nature, 1982, $298(5870)$ : $156-159$.

[30] Szelepcsényi Z, Breuer H, Kis A, Pongrácz R, Sümegi P. Assessment of projected climate change in the Carpathian Region using the Holdridge life zone system. Theoretical and Applied Climatology, 2018, 131(1/2) : 593-610.

[31] 孙鸿烈, 郑度, 姚檀栋, 张镱锂. 青藏高原国家生态安全屏障保护与建设. 地理学报, 2012, 67(1): 3-12.

[32] 中国科学院青藏高原综合科学考察队. 西藏自然地理. 北京: 科学出版社, 1982

[33] Myers N, Mittermeier R A, Mittermeier C G, da Fonseca G A B, Kent J. Biodiversity hotspots for conservation priorities. Nature, 2000, 403 (6772): 853-858.

[34] Zhang Y L, Hu Z J, Qi W, Wu X, Bai W Q, Li L H, Ding M J, Liu L S, Wang Z F, Zheng D. Assessment of effectiveness of nature reserves on the Tibetan Plateau based on net primary production and the large sample comparison method. Journal of Geographical Sciences, 2016, 26( 1 ) : 2744 .

[35] 郑度, 姚檀栋. 青藏高原隆升及其环境效应. 地球科学进展, 2006, 21(5): 451-458

[36] 姚檀栋, 朱立平. 青藏高原环境变化对全球变化的响应及其适应对策. 地球科学进展, 2006, 21(5): 459-464.

[37] Fan Z M, Bai R Y, Yue T X. Spatio-temporal distribution of vascular plant species abundance on Qinghai-Tibet Plateau. Journal of Geographical Sciences, 2019, 29(10): 1625-1636

[38］赵东升, 李双成, 吴绍洪. 青藏高原的气候植被模型研究进展. 地理科学进展, 2006, 25(4): 68-78.

[39］卓嘎，李欣，罗布，王彩云. 西藏地区近期植被变化的遥感分析.高原气象，2010，29(3):563-571

[40］廖清飞, 张金金, 马全, 姚瑶, 于东平.青海省东部农业区植被覆盖时空演变遥感监测与分析. 生态学报, 2014, 34(20)：5936-5943.

[41] Zhou D W, Fan G Z, Huang R G, Fang Z F, Liu Y Q, Li H Q. Interannual variability of the normalized difference vegetation index on the Tibetan Plateau and its relationship with climate change. Advances in Atmospheric Sciences, 2007, 24(3): 474-484

[42] Van Vuuren D P, Edmonds J, Kainuma M, Riahi K, Thomson A, Hibbard K, Hurtt G C, Kram T, Krey V, Lamarque J F, Masui T, Meinshausen M, Nakicenovic N, Smith S J, Rose S K. The representative concentration pathways: an overview. Climatic Change, 2011, 109(1/ 2) : 5 .

[43] Yue T X, Zhao N, Liu Y, Wang Y F, Zhang B, Du Z P, Fan Z M, Shi W J, Chen C F, Zhao M W, Song D J, Wang S H, Song Y J, Yan C Q, Li Q Q, Sun X F, Zhang L L, Tian Y Z, Wang W, Wang Y A, Ma S N, Huang H S, Lu Y M, Wang Q, Wang C L, Wang Y Z, Lu M, Zhou W, Liu Y, Yin X Z, Wang Z, Bao Z Y, Zhao M M, Zhao Y P, Jiao Y M, Naseer U, Fan B, Li S B, Yang Y, Wilson J P. A fundamental theorem for eco-environmental surface modelling and its applications. Science China Earth Sciences, 2020, 63(8) : 1092-1112.

[44] Yue T X. Surface Modelling: High Accuracy and High Speed Methods. New York: CRC Press, 2011.

[45] Yue T X, Zhao N, Fan Z M, Li J, Chen C F, Lu Y M, Wang C L, Xu B, Wilson J. CMIP5 downscaling and its uncertainty in China. Global and Planetary Change, 2016, 146: 30-37

[46] 范泽孟, 岳天祥, 陈传法. 全球平均气温未来情景的降尺度分析. 地理科学进展, 2012, 31(3): 267-274.

[47] Yue T X, Fan Z M, Liu J Y. Scenarios of land cover in China. Global and Planetary Change, 2007, 55(4): $317-342$.

[48] Yue T X, Li Q Q. Relationship between species diversity and ecotope diversity. Annals of the New York Academy of Sciences, 2010, 1195( S1) : E40-E51.

[49] Li L H, Zhang Y L, Wu J S, Li S C, Zhang B H, Zu J X, Zhang H M, Ding M J, Paudel B. Increasing sensitivity of alpine grasslands to climate variability along an elevational gradient on the Qinghai-Tibet Plateau. Science of the Total Environment, 2019, 678: 21-29. 